\title{
SERRATUS-INTERCOSTAL BLOCK IN PATIENTS UNDERGOING BREAST CANCER SURGERY: UTILITY
}

\section{Pérez Herrero. Hospital Clínico Universitario de Valladolid, Spain.}

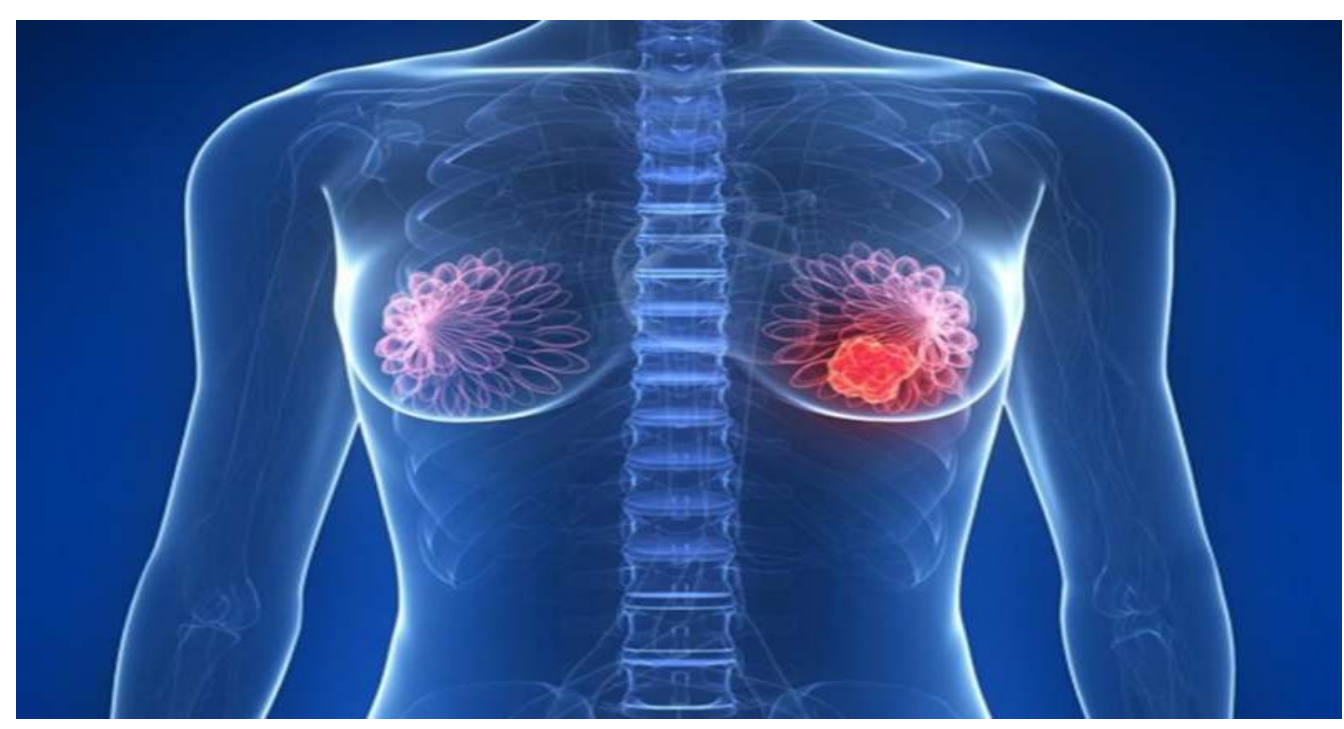

Introduction

Regional anesthesia is associated with decreased risk of complications after major surgery, but central blocks effects remain controversial in pheochromocytoma.

\section{Objetives:}

To evaluate the efficiency of serratus-intercostal analgesic blockade (intercostal branches in the axillary midline) in prevention of chronic pain after breast cancer surgery.

\section{Material \& Methods}

\section{Observational cohort study}

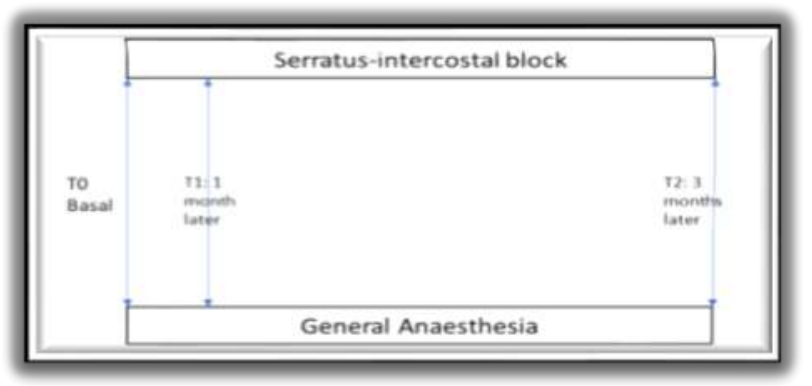

Prospective observational study in patients who signed consent. Inclusion criteria: age $\geq 18$ years, body mass index $<25$, ASA I-III and able to understand a numerical verbal scale (EVN from 0 to 10 ) to assess pain, breast surgery. rospective cohort study, that was approved by local Ethics Comitee with number PI 318.

All adult patients intervened in the period of one year (April 1th, 2017 to April 1th, 2018) were be included in a programmed form for breast cancer pathology (80 patients) under general anesthesia (control group, $\mathrm{n}=40$ ) or under anesthesia combined with serratus intercostal block $(n=40)$. Preoperative data predictors of chronic post-surgical pain (DCPQ) previously validated were analyzed: type of surgery, age, thoracic pain and pain in other areas of the body; Anesthetic-surgical data, intravenous analgesics, duration of the surgery and of the immediate postoperative period: EVA in the discharge of URPA, 24 hours post-intervention, and 1 month later; complications. Those that refered pain were reviewed to confirm the diagnosis of Chronic pain by sensory examination of the affected area, and to evaluate the Intensity of pain, its characteristics, and the degree of interference in the quality of life of the patient.

Statistical study of the data between the two groups using the Student's T test for continuous variables and the Chi-square test for continuous variables, considering significant values of $\mathrm{P}<0.05$.

\begin{tabular}{|c|c|c|}
\hline & General $(n=40)$ & Interfascial blockade $(n=40)$ \\
\hline Age (years) & $55+/-6(31-91)$ & $54+/-10(28-67)$ \\
\hline Weight (kg) & $57+/-9(44-98)$ & $50+/-5(47-90)$ \\
\hline High $(\mathrm{cm})$ & $156+/-7(145-185)$ & $162+/-5(154-185)$ \\
\hline ASA & $\begin{array}{l}1(25) \\
2(15)\end{array}$ & $\begin{array}{l}1(20) \\
2(12) \\
3(8)\end{array}$ \\
\hline Process & $\begin{array}{l}\text { Tumorectomy + Centynel node } \\
\text { biopsy (18) } \\
\text { Tumorectomy + linfadenectomy } \\
\text { (9) } \\
\text { Mastectomy (5) } \\
\text { Mastectomy + linfadenectomy (5) } \\
\text { Linfadenectomy (3) }\end{array}$ & $\begin{array}{l}\text { Tumorectomy + Centynel } \\
\text { node biopsy (20) } \\
\text { Tumorectomy + } \\
\text { linfadenectomy (8) } \\
\text { Mastectomy (6) } \\
\text { Mastectomy + linfadenectomy } \\
\text { (4) } \\
\text { Linfadenectomy (2) }\end{array}$ \\
\hline Side & $\begin{array}{l}\text { Left (30) } \\
\text { Right (10) }\end{array}$ & $\begin{array}{l}\text { Left (28) } \\
\text { Right (12) }\end{array}$ \\
\hline $\begin{array}{l}\text { Surgery } \\
\text { time (min) }\end{array}$ & $50+/-30(10-210)$ & $45+/-40(30-185)$ \\
\hline & $\begin{array}{l}\text { We found an average pain of 3, } 4 \text { (SD: 1,8) a } \\
\text { Chronic pain incidence: } 16 \% \text { one month afte } \\
\text { No complications for analgesic technique. } 10 \\
\text { (haematoma, surgical wound infection, serom, } \\
\text { No significative differences between groups. } \\
\text { Serratus-intercostal group was jounger. }\end{array}$ & $\begin{array}{l}\text { 1,2 (SD 0,5) } 3 \text { months later } \\
\text { urgery. } \\
\text { of surgical complications } \\
\text { paraesthesia) }\end{array}$ \\
\hline \multicolumn{3}{|c|}{$\begin{array}{l}\text { Conclusion(s) } \\
\text { Serratus-intercostal block is a efficient and safely technique in breast } \\
\text { surgery. } \\
\text { No significative differences between groups, but only in age. Study's } \\
\text { patients were jounger than control ones. }\end{array}$} \\
\hline
\end{tabular}

\section{References}

Pérez Herrero MA, López Álvarez S, Fadrique Fuentes A, Manzano Lorefice F, Bartolomé Bartolomé C, González de Zárate J. Calidad de la recuperación postquirúrgica tras cirugía de mama. Anestesia general combinada con bloqueo paravertebral versus bloqueo del espacio serrato-intercostal. Rev Esp Anestesiol Reanim. 2016; 63(10):564-571.

Ducic I, Seiboth LA, IorioML. Chronic postoperative breast pain: danger zones for nerve injuries. Plast Reconstr Surg 2011; 127(1): 41-6.. Meyer J-P et al. The treatment of high grade superficial bladder cancer and carcinoma in situ wwith BCG - a questionnaire survey of Consultant practice in England and Wales. Urol Oncol 2002; 2;: 77-80 . 